\title{
PA KUA MIRROR FUNCTION FOR CHINA ETHNISTS IN KOTAPINANG DISTRICT, LABUHANBATU SELATAN DISTRICT
}

\author{
Tri Rahma Dana ${ }^{1}$, Usman Pelly $^{2}$, and Ichwan Azhari ${ }^{3}$ \\ trirahmadana94@gmail.com \\ State University of Medan
}

\begin{abstract}
This study aims to determine the function of the Pa Kua mirror, namely a mirror with an octagonal shape, made of aluminium and silver which is believed to capture good things and ward off bad things that are usually placed outside the building above the entrance by the ethnic Chinese to live their lives, especially during the Covid-19 pandemic, a situation where all economic activities of many people have become paralyzed and even difficult to survive, such as in Kotapinang, South Labuhanbatu Regency. As the purpose of using this $\mathrm{Pa} \mathrm{Kua}$ mirror is a tradition passed down from generation to generation to be able to protect the buildings they inhabit. The research method used is descriptive qualitative. With the technique of collecting interview data, observation, and study documentation. The results of the analysis found that this mirror has been used for a long time by ethnic Chinese in their home country of China and has become a tradition they believe in banishing bad energies that enter their residence, and are brought by migrating Chinese ethnicities, especially in this Kotapinang sub-district. and used by those who still believe and still preserve the traditions of their ancestors today.
\end{abstract}

Keywords: function, Pa Kua mirror, Chinese ethnist, Covid-19 pandemic, descriptive qualitative

\section{INTRODUCTION}

The function is the usefulness of a thing for the life of a community, which if we draw the connection with this research is the depiction of the use of the Pa Kua mirror which we see a lot hanging above the entrance to buildings belonging to ethnic Chinese, especially ethnic Chinese in Kotapinang District, South Labuhanbatu Regency. This Ethnic Chinese have many traditions that they still 
practice today, for example, the tradition of installing a $\mathrm{Pa} \mathrm{Kua} \mathrm{mirror} \mathrm{above} \mathrm{the}$ entrance to the house or shop where they live or earn a living.

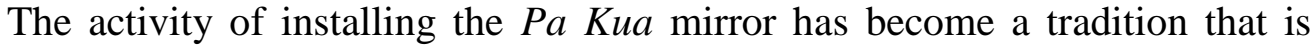
believed by the Chinese ethnic group from time to time to the present. If traced further in the existing historical records, this $\mathrm{Pa} \mathrm{Kua}$ mirror was discovered by Emperor Fu Xi (2600s-2800s) before the Xia dynasty in China. Emperor Fu Xi is thought to have lived in a period older than 5000 BC. Emperor Fu Xi was known to teach many people of his time in making nets, fishing and raising livestock, and created the mirror of $\mathrm{Pa} K u a$ himself. Due to his expertise in recognizing all changes that occur in nature and life forms including the movements of every member of the human body, the careful Emperor Fu Xi said that every movement in this universe moves according to the laws of nature or the laws of life. This octagonal mirror is divided into two forms, namely Convex (removes negative energy) and Concave (captures positive energy) made of aluminum and silver, believed by many ethnic Chinese to catch good things and repel bad things. Usually placed outside the house above the owner's house entrance. This mirror is a Feng Shui product that is believed to provide protection and things that are considered good for those who believe in it. The tradition of installing a $\mathrm{Pa} \mathrm{Kua}$ mirror was brought by ethnic Chinese who spread to all parts of the world from their country of origin, China.

Figure 1. Mirror Pa Kua

Source: Google.com

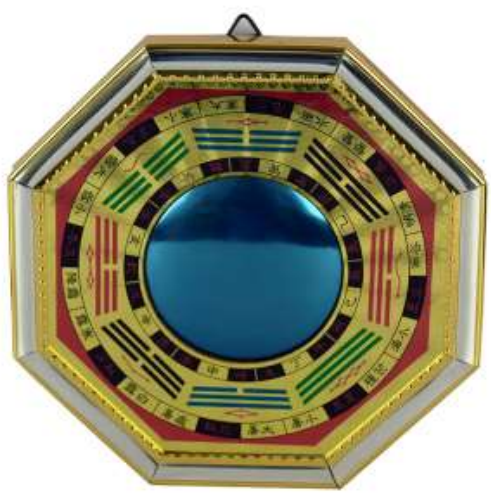

The spread of ethnic Chinese in various parts of the world has been going on for hundreds of years. From the 9th century onwards, Chinese traders frequently visited Java and Sumatra. It is estimated that around the 15th century, Chinese people have established relationships with local kings in the archipelago (Tan, 1991). Based on the source of the book entitled Deepening Chinese Thinking Patterns by Bloomfield (2010), it is written that in their home country 
China, China, installing a $\mathrm{Pa} \mathrm{Kua} \mathrm{mirror} \mathrm{is} \mathrm{important} \mathrm{to} \mathrm{protect} \mathrm{the} \mathrm{people} \mathrm{who}$ live in the house from these things. Negative and bad things that come from outside the home.

In 1973, the legendary actor Bruce Lee died at a very young age of 32 years and at that time many people in Kowloon, Hong Kong, where Bruce Lee lived, thought that Bruce Lee's death was caused by $\mathrm{Pa} \mathrm{Kua} \mathrm{mirror} \mathrm{that} \mathrm{was}$ installed on the tree in front of Bruce's house. Lee broke out in a typhoon wind just before his death. The earth necromancer or Feng Shui expert at the location of Bruce Lee's house suspected that the $P a K u a$ mirror was damaged due to bad Feng Shui in the residential area. It is not without reason why the area is named Kowloon which means nine dragons, and the name Bruce Lee Shiu Loong which means little dragon. The earth astrologer said the nine dragons were jealous of the presence of the little dragon Bruce Lee in Kowloon, which was at the peak of his brilliant career, so a hurricane broke $\mathrm{Pa} \mathrm{Kua}$ Bruce Lee's mirror and left Bruce Lee unprotected from negative energies that wanted to attack him. This news was even published in newspapers and made headlines in Hong Kong with the headline "Was Bad Feng Shui Really Killing Bruce Lee?" Even though the news of Bruce Lee's death is no longer a mystery because doctors have officially announced Bruce Lee's death due to a heart stroke which caused brain swelling and made Bruce Lee die. But some people who believe in the power of $\mathrm{Pa} \mathrm{Kua}$ mirror still think that part of the cause of death experienced by Bruce Lee is still because of the bad Feng Shui in Kowloon and because the $\mathrm{Pa} K u a$ mirror belonging to the action actor is damaged and cannot protect Bruce Lee from bad energy which came from outside his house.

Not only is the death of action actor Bruce Lee linked to the importance of using a $\mathrm{Pa} \mathrm{Kua} \mathrm{mirror,} \mathrm{there} \mathrm{are} \mathrm{still} \mathrm{many} \mathrm{bad} \mathrm{cases} \mathrm{that} \mathrm{occurred} \mathrm{in} \mathrm{Hong} \mathrm{Kong}$ at that time and are associated with the importance of installing a $\mathrm{Pa} K u a$ mirror at home. It is no different from how to install a $\mathrm{Pa} \mathrm{Kua} \mathrm{mirror} \mathrm{in} \mathrm{Hong} \mathrm{Kong,}$ China, or any part of the world where ethnic Chinese believe in the use of this $P a$ Kua mirror, installing this mirror should not be arbitrary, even how the position of this mirror is placed is also arranged in such a way that is not wrong and does not harm others in front of him. Indeed, in the problem of using the $\mathrm{Pa} K u a$ mirror, the deeper we look for it, the closer it will be to Feng Shui, because these two things are interrelated and related. As Bloomfield (2010) has mentioned in her book entitled Deepening Chinese Thinking Patterns, she summarizes some of the opinions of Feng Shui or earth astrologers which say that it takes a lifetime to understand the problems that exist in Feng Shui and to learn all its complexities. Therefore, the author here will not discuss widely about Feng Shui and will try to describe one of the Feng Shui products that are often found installed on the doors of the entrances of houses and shops belonging to ethnic Chinese as an effort to protect people who live in their buildings from energy- negative energy from outside that can endanger their lives and also as an effort to change their lives, as 
many Chinese people believe, that every hill, tree, pillar, door, window, gate, wall, and whatever it is and the direction facing it can affect life someone, so that those who want to change their environment can change their life, which is in line with the goal of Feng Shui, which is good harmony and in accordance with natural laws, as is done by ethnic Chinese in Kotapinang District, South Labuhanbatu Regency, North Sumatra.

\section{METHOD}

This type of research used in this research is descriptive qualitative. Qualitative research is descriptive research, namely research that emphasizes the perspective of the subject and the process. Bogdan and Taylor in Moleong (2010) explain that the qualitative research method is a research procedure in the form of descriptive data of written or spoken words from people as well as observable behavior. Meanwhile, descriptive research is one type of research whose purpose is to present a complete picture of a social setting or is intended for exploration and clarification of a social phenomenon or reality. The purpose of this descriptive research is to make descriptions, pictures or paintings systematically and the relationships between the phenomena being investigated (Nazir, 2009). This type of qualitative descriptive research describes the conditions as they are, without giving treatment or manipulation to the variables studied. This type of qualitative descriptive research is a type of research with the process of obtaining data as it is.

This research emphasizes the meaning of the results. Research subjects are informants, which means people in the research background are used to provide information about the situation and conditions of the research background. And the subject of this research is the Chinese ethnic who live in Kotapinang District, South Labuhanbatu Regency, amounting to 4 people, where 1 informant is an elder and guardian of a Vihara in Kotapinang, then 2 pro informants believe in Feng Shui and $\mathrm{Pa} \mathrm{Kua} \mathrm{mirror} \mathrm{and} \mathrm{applied} \mathrm{it} \mathrm{in} \mathrm{his} \mathrm{daily} \mathrm{life} \mathrm{and} \mathrm{one} \mathrm{informant}$ contra believes in Feng Shui and the Pa Kua mirror to be applied in his daily life. Informants were determined by determining informants based on Snowball Sampling.

There are several definitions of snowball. Firstly, snowball sampling technique is a method for identifying, selecting and taking samples in a network or continuous chain of relationships. The researcher presents a network through a Socio gram image in the form of a circle of images linked or connected by lines. Each circle represents a response and / or case, and the lines show the relationship between respondents or between cases (Neuman, 2015). Secondly, snowball sampling technique is a sampling method in which the sample is obtained through a rolling process from one respondent to another. Thirdly, this method is used to explain the social or communication patterns (sociometric) of a particular community. 
The data collection techniques used were in-depth interviews, observation and documentation study. The tools used to support the writing of this study used a voice recorder and a photo camera.

\title{
FINDINGS AND DISCUSSION
}

\section{Ethnic Chinese in North Sumatra}

In North Sumatra alone, the Chinese ethnic group consists of \pm 20 ethnic groups and 100 clans, where about $80 \%$ of the majority are Buddhists. The Chinese tribes that are often found in North Sumatra are the Hokkien, Teochiu, Khe (Hakka), Canton (Khong $\mathrm{Hu}$ ) and Liok Hong tribes, each of which has social associations with different professions and domiciles. For example, the Hokkien are generally traders who live mostly in the center of Medan, while the Teochiu generally work in agriculture, but some have turned into traders. The common areas inhabited by the Teochiu tribe are usually on the outskirts of Medan such as Sunggal, Pulo Brayan, to Stabat, to Pematang Siantar. The Cantonese usually worked as gold traders and carpenters, and they lived in urban areas. Meanwhile, the Khe tribe is generally engaged in the medicine and trade business, while the Liok Hong tribe mostly works as fishermen and live on the coast. Additionally, the Hainam tribe does a lot of business in the food sector. The accent language used by these Chinese tribes is different, but in general the language used as a trading language is Hokkien (Pelly, 2016).

The ethnic Chinese in Indonesia are classified into two, namely Peranakan Chinese and Totok Chinese. Totok ethnic Chinese are usually assigned to them ethnic Chinese who are immigrants who are all family members until their descendants still come from their native China, China and still maintain their language and culture in Indonesia. Meanwhile, the Peranakan Chinese are those Chinese who have assimilated into various cultures in Indonesia so that they have gradually changed the traditions of the Chinese ethnic culture who settled in Indonesia, and even the occurrence of ethnic Chinese marriages with ethnic groups outside the Chinese.

\section{Kotapinang, South Labuhanbatu, North Sumatra}

Kotapinang is a sub-district as well as the administrative center of South Labuhanbatu Regency, North Sumatra, Indonesia. The distance of this city is 345 $\mathrm{km}$ from the city of Medan, the capital of the province of North Sumatra. In the past, the capital of this sub-district, Kotapinang, which is also the capital of South Labuhanbatu Regency, was once the capital of the Sultanate of Kota Pinang.

\section{Figure 2. Map of Kotapinang District, South Labuhanbatu Regency}

\author{
Source: Google.com
}




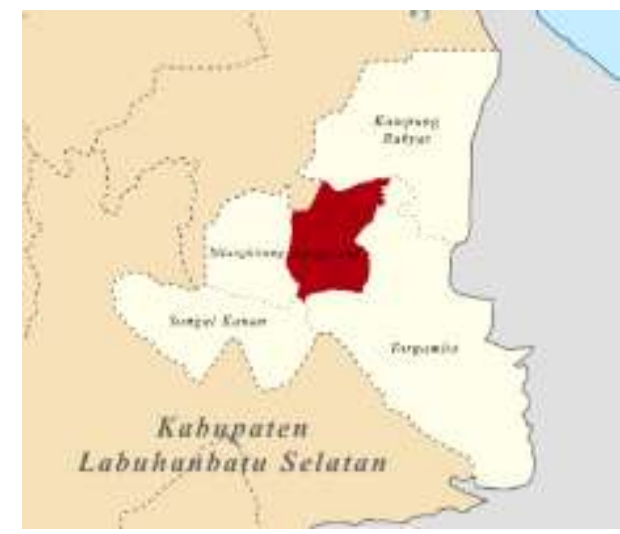

The ethnic Chinese in Kotapinang are an ethnic minority in this area, but even though they are a minority ethnicity, the Chinese are able to show their existence both in terms of their socialization life with other ethnicities and from an economic point of view which is known as the largest owner of capital in Indonesia. this region. The following is the population data according to ethnic groups in South Labuhanbatu Regency in 2010:

\section{Figure 3. Population data by ethnicity in South Labuhanbatu in 2010 (BPS} Labuanbatu Selatan, 2010)

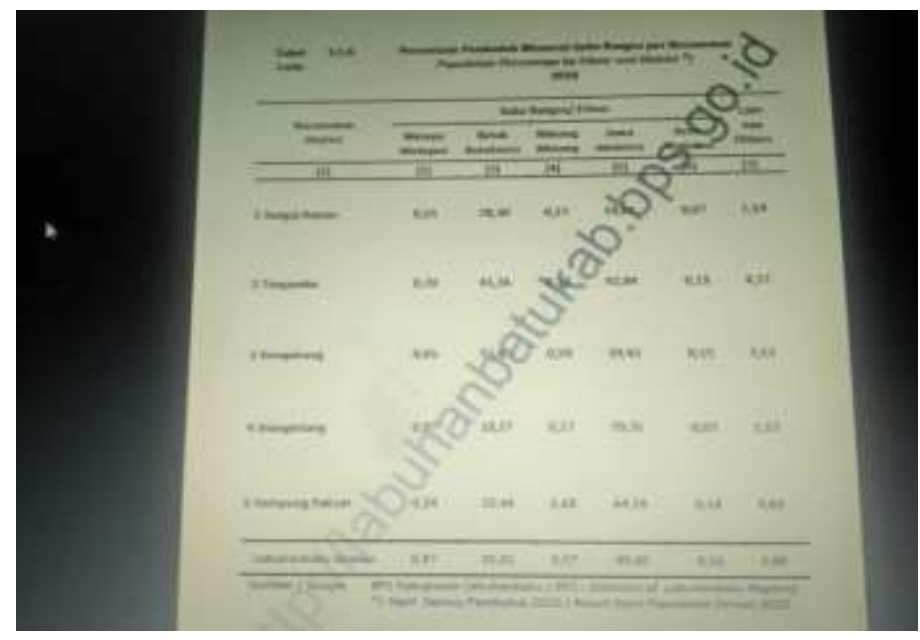

Whereas the dominant ethnic groups in Kotapinang District, South Labuhanbatu Regency are the Bataknese people with a rate of $55.65 \%$, while the Chinese ethnic groups are included in other categories that are members of other 
ethnic groups such as India, Arabic, and Chinese with a figure of $3.53 \%$. But even with very minority ethnic groups, they are able to become good economic center holders in this area.

\section{Pa Kua mirror and Feng Shui}

In Chinese literally, the word Feng Shui means wind and water. Indonesian sinologist expert from UI, Gondomono, said that Feng Shui is an energy that is intended to move all the energy in the universe through the configuration of land and water which eventually forms the earth. Feng Shui is also said to be the main source of prosperity, harmony, goodness, beneficial luck and at the same time the main source of bad luck that is detrimental to humans, depending on how we handle this so that the destructive attitude and changing the natural state by humans do not disturb the harmony of nature with humans.

Feng Shui is a science that has been passed down by traditional Chinese society from time to time until it has become a legacy carried by the descendants of Chinese society who we call ethnic Chinese in Indonesia who have spread to many regions in Indonesia, one of which is in Kotapinang District, South Labuhanbatu Regency, which has become the location of this research was conducted. The Chinese ethnic in Kotapinang who are pro with Feng Shui admit that Feng Shui is part of their cultural life. Many of their traditions always involve the use of Feng Shui. For example, to determine whether the position they live in is good which means avoiding the Yin (negative energy) around them, they believe in using a Feng Shui product called the $\mathrm{Pa} \mathrm{Kua/Ba} \mathrm{Gua} \mathrm{mirror.} \mathrm{This}$ mirror is in the shape of an octagonal, about an inch of an adult's hand, which is then hung above the entrance to the house. Before hanging the mirror, you must first recite prayers or meng-hoi kong (open his eyes) first the $\mathrm{Pa} \mathrm{Kua} \mathrm{mirror} \mathrm{to} \mathrm{a}$ Monastery or shrine that they believe in by Feng Shui experts, then hang it above the house entrance to ward off energy -negative energy that can endanger the residents of the house and to be able to avoid the Yin energy around the house. If

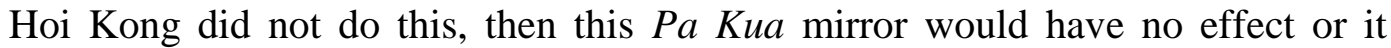
would be the same as an ordinary mirror. Meng-hoi kong means putting good Chi or energy into this $\mathrm{Pa} \mathrm{Kua} \mathrm{mirror.} \mathrm{After} \mathrm{hoi} \mathrm{kong,} \mathrm{this} \mathrm{Pa}$ Kua mirror can be used to fend off evil energy and absorb good energy.

What makes this $\mathrm{Pa} \mathrm{Kua}$ mirror so special to use by the Chinese ethnic group in Kotapinang is that this octagonal mirror has a meaning as a goodness for those who believe in it and use it in their lives. Because if we examine more deeply, the $\mathrm{Pa} \mathrm{Kua} \mathrm{mirror} \mathrm{contains} \mathrm{a} \mathrm{triagram} \mathrm{as} \mathrm{a} \mathrm{direction} \mathrm{and} \mathrm{five} \mathrm{elements} \mathrm{of}$ life that are believed by the Chinese themselves to prosper their lives, such as the elements of fire, water, earth, metal and wood. Each of these elements brings the good we need by using this $\mathrm{Pa} K u a$ mirror, for example, namely wealth, fame, family, a relationship, creativity and children, career, freedom, and helping others. 


\section{Figure 4. Pa Kua Mirror}

Source: google.com
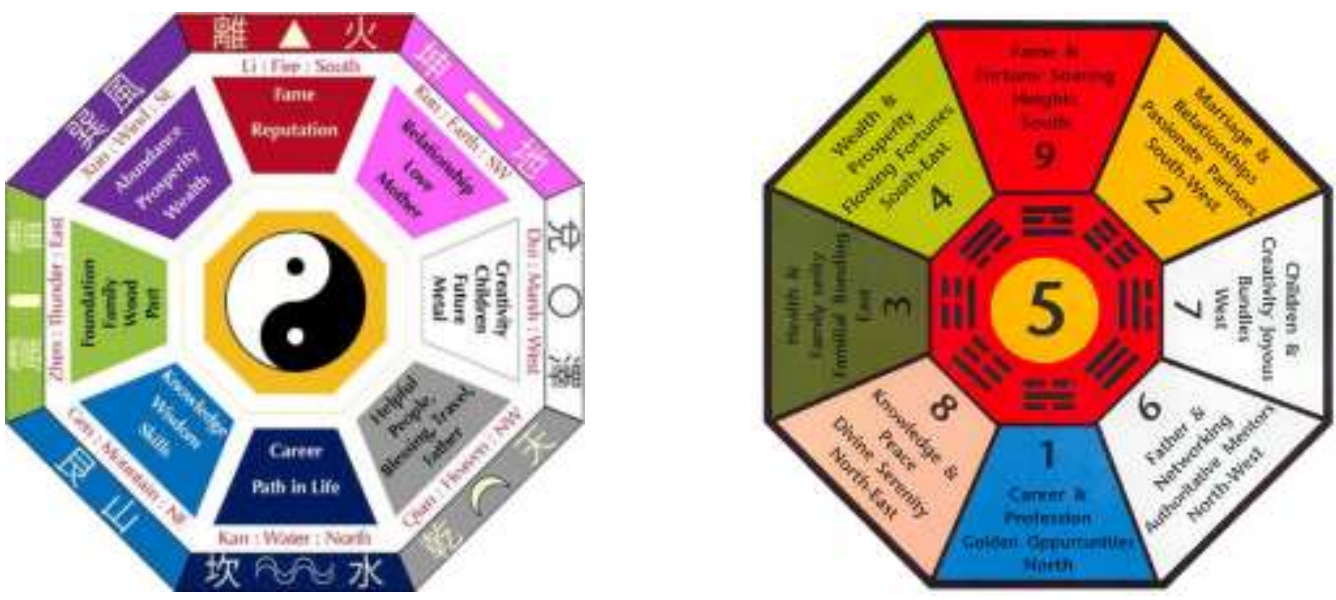

The $P a K u a$ mirror undergoes a change in shape from the past to the present. But the changes that occur do not make the $\mathrm{Pa} K u a$ mirror lose its meaning and function which has remained the same from the past until now, namely to ward off negative energy (Yin) and absorb positive energy (Yang). The traditional $\mathrm{Pa}$ Kua mirror is octagonal in shape and has a mirror in the center.

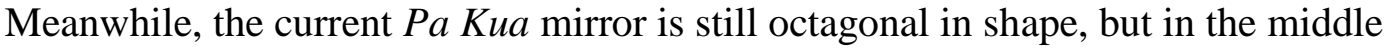
there is a mirror that no longer uses and has been replaced with the dragon and tiger symbols. Also, the materials used have changed, such as the traditional $\mathrm{Pa}$ Kua mirrors made of aluminum and silver, nowadays many of the $\mathrm{Pa} K u a$ mirrors are made of wood and even plastic. But the function of this $\mathrm{Pa} \mathrm{Kua \text {mirrordoes }}$ not change if the way it is used is done properly and according to the direction of the Feng Shui expert. Because the most important thing for the $\mathrm{Pa} \mathrm{Kua} \mathrm{mirror} \mathrm{to}$ function properly must be hoi kong or "open his eyes" first.

In a book entitled Feng Shui: Practical For Home by Albert Low (2003), in which he is the official Zen master, Dr. Albert Low was an authorized Zen master, an internationally published author, and a former human resources executive. He was born in London, England, on December 16, 1928. He has lived in England, South Africa, Canada, and the United States and has resided in Montreal from 1979 until his passing in 2016. He obtained a BA degree in Philosophy and Psychology and was a trained counselor. In 2003, he was awarded an honorary degree of Doctor of Laws for scholastic attainment and community service by Queen's University, Ontario, a prestigious Canadian University. He developed an original theory on creativity, organization, and management. Eventually wrote a book based on his researches: Zen and Creative Management which has since sold more than 75,000 copies. In 1966 he met a Japanese Zen 
Master, Yasutani, and practiced Zen first with him, and then for twenty years with Yasutani's chief disciple, Philip Kapleau. In 1976 he resigned from the Gas Company and went to Rochester Zen Center for three years where he served as editor of the Center's journal. In 1979 he relocated to Montreal as a probationary teacher. In 1986, he finished his training and was authorized to teach as a Zen master. Dr. Low made a study of human nature throughout his life. In writing his books he drew on his prolonged meditations on creativity and the human condition, his many years of providing psychological and spiritual counseling, and a wide-ranging knowledge of Western psychology, philosophy, and science (Amazon.com, n.d.).

In this book he said that to be able to use the $\mathrm{Pa} K u \mathrm{a}$ mirror appropriately and according to its purpose, the $\mathrm{Pa}$ Kua mirror must be hoi kong in Chinese or "open his eyes" if translated into Indonesian first so that it can function to reflect everything that is unwanted and perceived as a barrier. According to him, there are several ways to be able to hang out $\mathrm{Pa} \mathrm{Kua's} \mathrm{mirror,} \mathrm{it's} \mathrm{just} \mathrm{that} \mathrm{the} \mathrm{process} \mathrm{is}$ still a secret and no one has published it yet. He suggested, if it is difficult to find someone who can hoi kong $\mathrm{Pa} \mathrm{Kua's} \mathrm{mirror,} \mathrm{go} \mathrm{to} \mathrm{the} \mathrm{nearest} \mathrm{shrine} \mathrm{and} \mathrm{ask} \mathrm{a}$ priest there to hoi kong him. Then the question that arose in my mind was whether the ethnic Chinese in Kotapinang who chose to install this $\mathrm{Pa} \mathrm{Kua \text {mirrorhad }}$

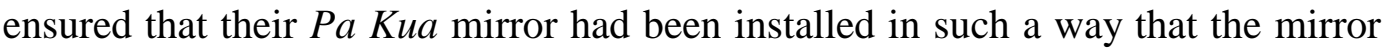
functioned as they expected, instead of just being an usual mirror? The following is the author's interview with several ethnic Chinese speakers in Kotapinang District, South Labuhanbatu Regency:

It turns out that believing in Feng Shui is not a must-have for ethnic Chinese, especially Chinese in Kotapinang. After making deeper observations, the writer found that there were some ethnic Chinese whose interview writers did not believe in the mirror of $P a K u a$ or Feng Shui, one of which is what I call Uak Akai (70), a Buddhist and who works as a The guardian of the Avalokitesvara monastery in Kotapinang said the following:

“... I don't believe in Feng Shui or Pa Kua's mirror. Indeed, I see many of my friends who wear mirrors, get banked at home, in the shop, but I don't believe it. After all, in our scriptures there is no mention of Feng Shui to be believed. For me, if people want to believe it, please, but I still don't believe it ..."

The Chinese ethnic distrust is caused because the scriptures they believe in do not teach the existence of Feng Shui to be believed as their way of life. But when there are parties who are contra in a problem, there must be parties who are pro. Some Chinese ethnic in Kotapinang also believe in Feng Shui and the Pa Kua mirror. The author asks why they believe in Feng Shui and the mirror of Pa Kua, 
one of the informants, Hui Eng (58), a photocopy businessman in Kotapinang and a Buddhist, answered as follows:

“... Feng Shui is not a heretical teaching, Feng Shui is the science of earth astrology which has a good purpose, helping people to live in harmony with nature. Even though neither Feng Shui nor Pa Kua's mirror is written in the religious scriptures that I believe, studying science with a good purpose is not a problem ..."

Choosing to believe it or not will indeed return to each individual, as the pros and cons of a problem are also natural, because everyone's views must be different, especially since the perspectives used are different. There is nothing wrong with having different opinions about what we want to believe as our way of life, returning to life is a choice, please choose what way of life you want to be like. That is what Mrs. Hui Eng wants to convey as an ethnic Chinese in Kotapinang and as a person who believes in using the $\mathrm{Pa} \mathrm{Kua} \mathrm{mirror} \mathrm{as} \mathrm{a} \mathrm{barrier}$ to bad energy from outside her shop. Furthermore, the authors asked how the correlation between installing the $\mathrm{Pa} \mathrm{Kua}$ mirror and the level of income generated by the shop especially during the Covid-19 virus pandemic which had lasted almost a full year in 2020, and according to Mrs. Hui Eng as follows:

"... No one can guarantee that something can be according to what we want, all return to God as the creator of the universe and we as humans are given our minds to be able to dig up as much knowledge as possible, one of which is Feng Shui which is wellintentioned. to harmonize human life with nature. I'm not saying that because this Pa Kua mirror that I put up in my shop makes me rich, but by installing this $\mathrm{Pa}$ Kua mirror in my shop, I have put up my hopes and prayers that bad energies can be resisted by this mirror and helps me in making a good living ..."

The answer given by Mrs. Hui Eng was very good and still not enough to complete the author's curiosity about the correlation between $\mathrm{Pa} \mathrm{Kua's} \mathrm{mirror} \mathrm{and}$ his economic problems during the Covid-19 pandemic as evidence also that the $\mathrm{Pa}$ Kua mirror did show a good impact for Users, the author tries to ask Mrs. Hui Eng whether the mirror installation has an impact when the economy of many people declines in 2020 due to the Covid-19 pandemic, and she replied: 
“... Praise God, my income in 2020 can still support me and my extended family to survive when there are some people who cannot survive this difficult time..."

According to Mrs. Hui Eng, installing a $\mathrm{Pa} \mathrm{Kua} \mathrm{mirror} \mathrm{is} \mathrm{a} \mathrm{form} \mathrm{of} \mathrm{her}$ effort to make her life better as she wants. Choosing to believe in Feng Shui and the mirror of $\mathrm{Pa} \mathrm{Kua}$ is a way of life that he has chosen because it is something that has been taught by his family from the past until now, and according to him it is also up to each person how he chooses to believe in things like this or not, because life is selection. From Mrs. Hui Eng, it can be seen that not all ethnic

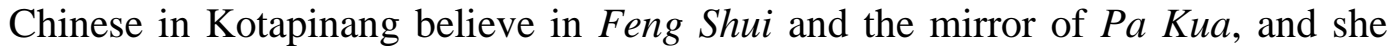
chooses to believe because it has become a tradition taught by her family to be able to ward off bad energies from outside to use mirrors. Pa Kua and according to him are also the mirror of $\mathrm{Pa} \mathrm{Kua}$ 's part in improving his economic situation during a difficult time like in 2020, which is the year when the Covid-19 virus pandemic has paralyzed the economies of many people in Indonesia and the world.

The author continues the interview with an ethnic Chinese, namely Mrs. Wina (60), whose activity is a housewife, is a Buddhist, and installs a $\mathrm{Pa} \mathrm{Kua} \mathrm{mirror}$ above the main entrance of her house;

“... Oh this Pa Kua mirror has been installed in my house for a long time, its purpose is to repel bad things, for example, my house faces a crossroads which is usually considered bad in Feng Shui, so to protect my family who was in my house was told to install this $\mathrm{Pa}$ Kua mirror ..."

Mrs. Wina chose to use the Pa Kua mirror because her house was facing a crossroads which according to Feng Shui was not good and she was advised by her relatives who are also Chinese to use the $\mathrm{Pa}$ Kua mirror to avoid bad energies that want to enter her house. There isn't much that can be asked of Mrrs. Wina because she only works as a housewife and says that she doesn't know Feng Shui and $\mathrm{Pa} \mathrm{Kua's} \mathrm{mirror} \mathrm{in} \mathrm{more} \mathrm{detail.} \mathrm{He} \mathrm{only} \mathrm{said} \mathrm{that} \mathrm{he} \mathrm{had} \mathrm{heard} \mathrm{about} \mathrm{Feng}$ Shui from his friends and family but did not go into it further and put up the $P a$ Kua mirror because he felt the explanation about installing the mirror made more logical sense and also wanted his house not to get bad energy because it was at a crossroads street.

\section{CONCLUSION}

Feng Shui is an energy that is intended to move all the energy in the universe through the configuration of land and water which eventually forms the earth. 
Feng Shui is also said to be the main source of prosperity, harmony, goodness, beneficial luck and at the same time the main source of bad luck that is detrimental to humans, depending on how we handle this so that the destructive attitude and changing the natural state by humans do not disturb the harmony of nature with humans. Feng Shui is a science that has been passed down by traditional Chinese society from time to time until it has become a legacy carried by the descendants of Chinese society who we call ethnic Chinese in Indonesia who have spread to many regions in Indonesia, one of which is in Kotapinang District, South Labuhanbatu Regency, which has become the location of this research was conducted.

The Chinese ethnic in Kota Kotapinang who are pro with Feng Shui admit that Feng Shui is part of their cultural life. Many of their traditions always involve the use of Feng Shui. For example, to determine whether the position they live in is good - which means avoiding the Yin (negative energy) around them, they believe in using a Feng Shui product called the $\mathrm{Pa} \mathrm{Kua} \mathrm{/} \mathrm{Ba} \mathrm{Gua} \mathrm{mirror.} \mathrm{This}$ mirror is in the shape of an octagonal, about an inch of an adult's hand, which is then hung above the entrance to the house. Before hanging the mirror, you must first recite prayers or meng-hoi kong (open his eyes) first the $\mathrm{Pa} \mathrm{Kua} \mathrm{mirror} \mathrm{to} \mathrm{a}$ Monastery or shrine that they believe in by Feng Shui experts, then hang it above the house entrance to ward off energy -negative energy that can endanger the residents of the house and to be able to avoid the Yin energy around the house. If hoi kong did not do this, then this $\mathrm{Pa} \mathrm{Kua} \mathrm{mirror} \mathrm{would} \mathrm{have} \mathrm{no} \mathrm{effect} \mathrm{or} \mathrm{it} \mathrm{would}$ be the same as an ordinary mirror. Meng-hoi kong means putting good Chi or energy into this $\mathrm{Pa} \mathrm{Kua}$ mirror. After hoi kong, this $\mathrm{Pa}$ Kua mirror can be used to

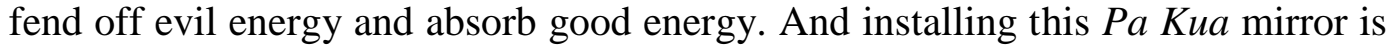
not a necessity that Chinese ethnic groups, especially those in Kotapinang, have to do, because in fact some Chinese themselves choose to believe and not believe. Even so Feng Shui and the Pa Kua mirror still have a good purpose for its users and good things can not only be used by one ethnicity, which is where the author's intention here is that the author learns something from the Zen master Albert Low, who is not Chinese, can learn and devote himself as a Zen master who can help people avoid bad Feng Shui by installing a $\mathrm{Pa} \mathrm{Kua} \mathrm{mirror} \mathrm{over} \mathrm{the} \mathrm{entrance} \mathrm{to}$ their building. Life is a choice which remains us as humans how to decide how we will live our lives to be better.

\section{REFERENCES}

Bloomfield, F. (2010). Chinese Beliefs: Mendalami Pola-pola Berfikir Orang Cina. Surabaya: Liris.

Chandramulyana, S. (2007). Ba Zi. Jakarta: PT Elex Media Komputindo.

Darmayanti, T. E. \& Sondang, S. (2014). Pendekatan Feng Shui Dengan Metode Ba Zi Pada Desain Interior. Jurnal Waca Cipta Ruang. 1 (1): 1-10. 
Gondomono. (1996). Membanting Tulang Menyembah Arwah: Kehidupan Kekotaan Masyarakat Cina. Jakarta: Pustaka Firdaus.

Gungwu, W. (1991). Kajian Tentang Identitas Orang Cina di Indonesia dalam Perubahan Identitas Orang Cina di Asia Tenggara. Terjemahan Ahmad. Jakarta : Grafiti Press.

Kustedja, S. Sudikno, A. \& Salura, P. (2012a). Kosmologi Media Interpretasi Makna pada Arsitektur Tionghoa Tradisonal. Jurnal Sosioteknologi. 27 (11): 194-231

Kustedja, S. Sudikno, A. \& Salura, P. (2012b). Feng-shui: Elemen Budaya Tionghoa Tradisional. Melintas. 28 (1): 61-89.

Low, A. (2003). Feng Shui Praktis Untuk Rumah Tangga. Jakarta: Megapoin.

Madeddu, M. \& Zhang, X. (2017). Harmonious Spaces: The Influence of Feng Shui on Urban Form and Design. Journal of Urban Design.

Moleong, L. J. (2010). Metodologi Penelitian Kualitatif. Bandung: Remaja Rosdakarya.

Morgan, H. T. (2007). China Simbol dan Mistik. Yogyakarta: Alfamedia.

Nazir, M. (2009). Metode Penelitian. Jakarta: Ghalia Indonesia.

Neuman, W. L. (2015). Metodologi Penelitian Sosial: Pendekatan Kualitatif dan Kuantitatif. Jakarta. PT Indeks.

Pelly, U. (2016). Etnis Tionghoa Dalam Masyarakat Multikultural Indonesia. Medan: Perdana Publishing \& Casa Mesra Publisher.

Simons, T. R. (2005). The Feng Shui of Love. Yogyakarta: Baca.

Spradley, J. P. (2006). Metode Etnografi. Jakarta: TWY.

Too, L. (1995). Feng Shui. Jakarta: PT. Elex Media Komputindo.

Tan, M. G. (1991). Golongan Etnis Tionghoa di Indonesia, Suatu Masalah Pembinaan Kesatuan Bangsa. Jakarta: PT. Gramedia.

Rahardjo, M. (2004). Mengubah Energi Rumah Meningkatkan Peruntungan. Jakarta: Gramedia.

Wijaya, B. (2016). Mengungkap Rahasia Karakter dan Keberuntungan Hidup dengan Shio Astrologi China. Yogyakarta: Psikopedia.

Yi, X. (2015). Kenali Elemen Dirimu, Bukan Shio!. Jakarta: BIP. 